\title{
Serum ferritin level is higher in male adolescents with obesity: results from the Korean National Health and Nutrition Examination Survey 2010
}

\author{
Yeon Jin Jeon, $\mathrm{MD}^{1}$, \\ In Ah Jung, $M D^{1}$, \\ Shin Hee Kim, MD', \\ Won-Kyoung Cho, MD', \\ Seung Hee Jeong, $\mathrm{PhD}^{2}$, \\ Kyoung Soon Cho, MD', \\ So Hyun Park, MD', \\ Min Ho Jung, MD', \\ Byung-Kyu Suh, MD' \\ ${ }^{1}$ Department of Pediatrics, \\ The Catholic University of Korea \\ College of Medicine, Seoul, ${ }^{2}$ Clinical \\ Research Coordinating Center of \\ Catholic Medical Center, Seoul, \\ Korea
}

Received: 4 September, 2013 Revised: 26 September, 2013 Accepted: 27 September, 2013

Address for correspondence: Byung-Kyu Suh, MD

Department of Pediatrics, Seoul St. Mary's Hospital, The Catholic University of Korea College of Medicine, 222 Banpo-daero, Seocho-gu, Seoul 137-701, Korea Tel: +82-2-2258-6185

Fax: +82-2-532-6185

E-mail:suhbk@catholic.ac.kr

Co-correspondence:

Won-Kyoung Cho, MD

Department of Pediatrics, Seoul St. Mary's Hospital, The Catholic University of Korea College of Medicine, 222 Banpo-daero, Seocho-gu, Seoul 137-701, Korea

Tel: +82-2-2258-6194

Fax: +82-2-532-6185

E-mail:wendy626@catholic.ac.kr
Purpose: Previous reports show an association between high serum ferritin levels and metabolic syndrome (MS) in adults. In adolescents, little information is available with obesity and serum ferritin levels.

Methods: This is a cross-sectional study. Data were obtained from the 5th Korean National Health and Nutrition Examination Survey (K-NHANES) conducted during 2010 by the Korean Ministry of Health and Welfare. A total of 849 subjects aged 10-18 years participated in the 2010 survey. A body mass index (BMI) $\geq 95$ th percentile for age and sex or a $\mathrm{BMI} \geq 25$ was used to diagnose as obesity.

Results: The weighted prevalence of obesity was 13.4\% (62/462) in male and $8.5 \%$ $(33 / 387)$ in female. We observed significantly higher serum ferritin in male than in female (mean \pm standard error [SE], $50.5 \pm 2.3 \mu \mathrm{U} / \mathrm{L}$ vs. $30.6 \pm 1.3 \mu \mathrm{U} / \mathrm{L} ; P<0.0001$ ). In male, serum ferritin is positively correlated with age $(P<0.0001)$. White blood cell (WBC) count, serum fasting blood sugar, triglyceride (TG), total cholesterol, lowdensity lipoprotein, insulin, homeostasis model assessment-insulin resistance (HOMAIR), systolic and diastolic blood pressure, and ferritin levels were higher and highdensity lipoprotein (HDL) were lower in the obesity than in the normal group. In female adolescents, WBC count, TG, insulin, and HOMA-IR were higher and HDL were lower in the obesity than in the normal group. In male, serum ferritin levels showed positive association with obesity $(\beta=21.196, P=0.016)$.

Conclusion: Serum ferritin levels appear to be associated with obesity in Korean male adolescents.

Keywords: Ferritins, Adolescent, Obesity, Male, Korean

\section{Introduction}

The prevalence of childhood obesity has significantly increased worldwide and has become an important global public health issue ${ }^{1)}$. Similar changes in the prevalence of childhood obesity have been observed in South Korea, owing to changes in lifestyle and nutritional habits ${ }^{2}$. According to the Korean National Growth Surveys conducted in 1997 and 2005, the prevalence of obesity in children and adolescents, as defined by age and sex specific body mass index (BMI) percentiles ( $\geq 95$ th percentile) or BMI $\geq 25 \mathrm{~kg} / \mathrm{m}^{2}$, has increased 1.7 -fold from $5.8 \%$ in 1997 to $9.7 \%$ in 2005 . In boys, the prevalence of obesity increased 1.9 -fold from $6.1 \%$ in 1997 to $11.3 \%$ in 2005, whereas in girls, it increased 1.5 -fold from 5.5\% in 1997 to $8.0 \%$ in $2005^{3)}$.

Childhood obesity is associated with complications such as abnormal growth acceleration, glucose intolerance, hypertension, dyslipidemia, nonalcoholic fatty liver disease, polycystic ovary syndrome, pseudotumor cerebri, and psychological problems ${ }^{4-6}$. Childhood obesity should be taken seriously because it is a risk factor for cardiovascular diseases and metabolic 
syndrome (MS) in adulthood and thus affects morbidity and mortality in later life ${ }^{7,8)}$.

Serum ferritin is a widely used clinical biomarker in various epidemiological studies ${ }^{9}$. Ferritin not only reflects body iron stores in healthy individuals, but also is an acute phase reactant and can be artificially elevated in the presence of systemic inflammation ${ }^{10,11)}$. Inflammatory reactions play an important role in metabolic disorders, such as insulin resistance, adiposity, atherosclerosis, and diabetes ${ }^{12)}$. Previous studies have reported that increased serum ferritin in adults is associated with central obesity $^{13,14)}$ MS $^{15-18)}$, essential hypertension ${ }^{19)}$, dyslipidemia ${ }^{20)}$, insulin resistance ${ }^{12,21,22)}$, nonalcoholic fatty liver disease ${ }^{23)}$, and diabetes mellitus ${ }^{17,24)}$. However, only a few studies have reported on the relationship between serum ferritin and childhood obesity.

Therefore, we conducted a cross-sectional study based on data obtained in the 2010 Korean National Health and Nutrition Examination Survey (K-NHANES) to explore the association between elevated serum ferritin level and obesity in Korean male adolescents.

\section{Materials and methods}

\section{Subjects}

This study was based on data obtained from the fifth K-NHANES conducted in 2010 by the Korean Ministry of Health and Welfare. K-NHANES surveys are conducted annually using a rolling sampling design that involves a complex, stratified, multistage, probability-cluster survey of a representative sample of the noninstitutionalized civilian population in south Korea. All individuals are randomly selected.

A total of 8,958 people participated in the 2010 K-NHANES we limited our study to adolescents aged $10-18$ years, and 1,076 subjects were thus included in our analysis. Among these subjects, those with missing data were excluded, resulting in a study population of 849 adolescents (male, 462; female, 387).

\section{Measurements}

Height and weight measurements were performed with the participants wearing light clothing and no shoes. BMI was calculated as weight in kilograms divided by the square of height in meters. A high BMI is a moderately sensitive and very specific indicator of excess adiposity in children ${ }^{25)}$. A BMI $\geq 95$ th percentile or BMI $\geq 25$ was used to diagnose obesity ${ }^{3,26)}$. In this study, adolescents diagnosed as obesity were classified as obesity group and the rest were normal group. Waist circumference (WC) was measured between the rib cage and the iliac crest to the nearest $0.1 \mathrm{~cm}$ in a standing position. A WC $\geq 90$ th percentile for age and sex was used to diagnose abdominal obesity. Blood pressure (BP) was measured while subjects were in a sitting position following a 5 -minutes rest period. Systolic BP and diastolic BP were measured by a mercury sphygmomanometer (Baumanometer, W. A. Baum Co., Copiague, NY, USA) on the right arm. To assess serum levels of biochemical markers, blood samples were obtained from the antecubital veins of the subjects following an overnight, 10-12 hours fast. Serum levels of fasting blood sugar (FBS), total cholesterol (TC), triglyceride (TG), high-density lipoprotein (HDL) cholesterol, low-density lipoprotein (LDL) cholesterol, alanine aminotransferase (serum glutamic pyruvic transaminase), aspartate aminotransferase (serum glutamic oxaloacetic transaminase), and $\gamma$-glutamyl transpeptidase were measured using an enzymatic method (Hitachi Automatic Analyzer 7600, Hitachi, Tokyo, Japan). Blood hemoglobin $(\mathrm{Hb})$ levels were measured with an XE-2100D (Sysmex, Tokyo, Japan). Insulin levels were measured using a gamma counter (1470 Wizard; Perkin-Elmer, Turtu, Finland) with an immunoradiometric assay (Biosources, Nivelles, Belgium). The intra- and inter-assay coefficients of variation were $1.6-2.2 \%$ and $6.1-6.5 \%$, respectively. Insulin resistance was determined using the homeostasis model assessment of insulin resistance $(\mathrm{HOMA}-\mathrm{IR}=$ fasting glucose $[\mathrm{mmol} / \mathrm{L}] \times$ fasting insulin $[\mu \mathrm{U} / \mathrm{mL}] / 22.5)$. Serum ferritin was measured by immunoradiometric assay (IRMA) using IRMA-mat Ferritin (DiaSorin, Stillwater, MN, USA)

\section{Statistical analyses}

All statistical analyses were carried out using SAS ver. 9.2 (SAS Institute Inc., Cary, NC, USA) were two-sided, and $P$-values of less than 0.05 were considered statistically significant.

To make valid inferences accounting for the K-NHANES 2010 complex multistage sampling design, sampling weights were incorporated to produce population estimates. The survey sample weights were calculated taking into consideration the sampling rate, response rate, and proportion of the reference population (2005 Korean National Census Registry), and were used in all analyses to produce estimates representative of children and adolescents aged 10 to 18 years.

All data are presented as mean \pm standard error (SE) for continuous variables and frequency percentage (SE) for categorical variables. All analyses were performed separately for males and females. Missing data according to each variable were excluded from the P-value computation for the relevant analysis.

The mean values of continuous variables were compared using SAS proc surveymeans procedures. Differences in the proportion of participants who had obesity were analyzed using SAS proc surveyfreq procedures. Serum ferritin was not normally distributed, and geometric means were obtained as representative values. Fig. 1 illustrates the relationship between age and serum ferritin, and we calculated the beta (slope) and $\mathrm{SE}$ of the linear regression model with proc surveyreg. The associations between MS components and serum ferritin were analyzed using proc surveyreg, and the covariate for the adjusted beta (slope) calculation was age. 


\section{Results}

\section{General characteristics of the study population}

The clinical characteristics of the study subjects are listed in Table 1. Among the 849 participants, 462 (54.4\%) were male and 387 (45.6\%) were female. There were no significant differences in the mean age of the female and male. Compared with the female, the male had higher mean values for $\mathrm{Hb}(14.6 \pm 0.1 \mathrm{~g} /$ dL vs. $13.3 \pm 0.1 \mathrm{~g} / \mathrm{dL}, P<0.0001$ ), hematocrit (Hct; $42.9 \% \pm 0.2 \%$ vs. $39.6 \% \pm 0.2 \% ; P<0.0001)$, systolic BP $(106.3 \pm 0.7 \mathrm{mmHg}$ vs. $101.9 \pm 0.7 \mathrm{mmHg}, P<0.0001)$, iron $(114.7 \pm 2.67 \mu \mathrm{U} / \mathrm{dL}$ vs. $99.9 \pm 2.4 \mu \mathrm{U} / \mathrm{dL}, P<0.0001)$, and mean serum ferritin $(50.5 \pm 2.3$ $\mu \mathrm{U} / \mathrm{L}$ vs. $30.6 \pm 1.3 \mu \mathrm{U} / \mathrm{L}, P<0.0001)$ (Table 1 ).

\section{The association between the age and serum ferritin by sex}

A significantly positive association between serum ferritin and age was observed in male $(\beta=5.647, P<0.0001)$, but not in female $(\beta=0.227, P=0.686)$ (Fig. 1$)$.

\section{Comparison of the general characteristics and laboratory data between the obesity and normal group of Korean male adolescents}

The weighted prevalence of obesity in male was $13.4 \%$ (62/462). No differences were observed between the average ages in the obesity and normal groups. Compared to the normal group, the obesity group showed significantly higher levels for WBC count $\left(6.9 \pm 0.210^{9} / \mathrm{L}\right.$ vs. $\left.6.0 \pm 0.110^{9} / \mathrm{L}, P<0.0001\right)$, FBS $(91.1 \pm 1.1 \mathrm{mg} / \mathrm{L}$ vs. $88.8 \pm 0.4 \mathrm{mg} / \mathrm{L}, P=0.040)$, TC $(170.7 \pm 5.2$ $\mathrm{mg} / \mathrm{dL}$ vs. $149.5 \pm 1.6 \mathrm{mg} / \mathrm{dL}, P=0.0001), \mathrm{TG}(126.8 \pm 9.4 \mathrm{mg} / \mathrm{dL}$ vs. $77.2 \pm 2.7 \mathrm{mg} / \mathrm{dL}, P<0.0001)$, LDL cholesterol $(119.8 \pm 6.4$ $\mathrm{mg} / \mathrm{dL}$ vs. $86.1 \pm 2.0 \mathrm{mg} / \mathrm{dL}, P=0.0001)$, insulin $(20.9 \pm 1.4 \mu \mathrm{U} /$ $\mathrm{mL}$ vs. $12.1 \pm 0.3 \mu \mathrm{U} / \mathrm{mL}, P<0.0001)$, HOMA-IR ( $4.7 \pm 0.3$ vs. $2.7 \pm 0.1, P<0.0001)$, systolic BP $(116.1 \pm 1.8 \mathrm{mmHg}$ vs. $104.8 \pm 0.8$ $\mathrm{mmHg}, P<0.0001)$, diastolic BP $(69.0 \pm 1.6 \mathrm{mmHg}$ vs. $63.7 \pm 0.7$ $\mathrm{mmHg}, P=0.003)$, and ferritin $(68.9 \pm 9.4 \mu \mathrm{U} / \mathrm{L}$ vs. $47.7 \pm 2.0 \mu \mathrm{U} / \mathrm{L}$, $P=0.027)$. HDL cholesterol was significantly lower in the obesity group than in the normal group $(44.0 \pm 1.5 \mathrm{mg} / \mathrm{dL}$ vs. $48.6 \pm 0.5$ $\mathrm{mg} / \mathrm{dL}, P=0.002) . \mathrm{Hb}(14.8 \pm 0.2 \mathrm{~g} / \mathrm{dL}$ vs. $14.6 \pm 0.1 \mathrm{~g} / \mathrm{dL}, P=0.179)$, Hct $(43.7 \% \pm 0.5 \%$ vs. $42.8 \% \pm 0.2 \%, P=0.059)$, and iron $(115.0 \pm 6.2$ $\mu \mathrm{U} / \mathrm{dL}$ vs. $114.6 \pm 2.8 \mu \mathrm{U} / \mathrm{dL}, P=0.952)$ levels were higher in the obesity group than in the normal group, but the differences were not statistically significant (Table 2).

\section{Comparison of the general characteristics and laboratory data between the obesity and normal group of Korean female adolescents}

The weighted prevalence of obesity in the female was $8.5 \%$ $(33 / 387)$. The mean age was significantly higher in the obesity group than in the normal group $(15.4 \pm 0.5$ vs. $14.0 \pm 0.2, P=0.005)$. Compared to the normal group, the obesity group showed significantly higher levels for WBC count $\left(6.8 \pm 0.210^{9} / \mathrm{L}\right.$ vs. $\left.6.0 \pm 0.110^{9} / \mathrm{L}, P=0.001\right)$, TG $(107.0 \pm 11.4 \mathrm{mg} / \mathrm{dL}$ vs. $83.3 \pm 3.5$ $\mathrm{mg} / \mathrm{dL}, P=0.043)$, insulin $(17.0 \pm 1.7 \mu \mathrm{U} / \mathrm{mL}$ vs. $13.3 \pm 0.4 \mu \mathrm{U} / \mathrm{mL}$, $P=0.021)$, HOMA-IR (3.8 \pm 0.4 vs. $2.9 \pm 0.1, P=0.014)$, and lower levels of HDL cholesterol $(43.5 \pm 1.8 \mathrm{mg} / \mathrm{dL}$ vs. $51.4 \pm 0.6 \mathrm{mg} /$ $\mathrm{dL}, P=0.0002)$; however, no difference in $\mathrm{Hb}(13.3 \pm 0.1 \mathrm{~g} / \mathrm{dL}$ vs. $13.3 \pm 0.1 \mathrm{~g} / \mathrm{dL}, P=0.655)$ or Hct $(39.7 \% \pm 0.4 \%$ vs. $39.6 \% \pm 0.2 \%$, $P=0.910)$ levels were observed. Although, not statistically significant, the obesity group had higher levels of FBS $(89.9 \pm 1.8$ $\mathrm{mg} / \mathrm{L}$ vs. $88.3 \pm 0.4 \mathrm{mg} / \mathrm{L}, P=0.040)$, LDL cholesterol $(99.4 \pm 7.0$

Table 1. Multiple parameters by sex for children and adolescents aged 10 to 18 years; the Korean National Health and Nutrition Survey

\begin{tabular}{|c|c|c|c|}
\hline Characteristic & Male $(n=462)$ & Female $(n=387)$ & $P$-value \\
\hline Age (yr) & $14.2 \pm 0.1$ & $14.1 \pm 0.2$ & 0.7770 \\
\hline $\mathrm{Hb}(\mathrm{g} / \mathrm{dL})$ & $14.6 \pm 0.1$ & $13.3 \pm 0.1$ & $<0.0001$ \\
\hline Hct (\%) & $42.9 \pm 0.2$ & $39.6 \pm 0.2$ & $<0.0001$ \\
\hline WBC $\left(10^{9} / L\right)$ & $6.2 \pm 0.1$ & $6.1 \pm 0.1$ & 0.6990 \\
\hline FBS (mg/L) & $89.1 \pm 0.4$ & $88.5 \pm 0.4$ & 0.2250 \\
\hline $\mathrm{TC}(\mathrm{mg} / \mathrm{dL})$ & $152.40 \pm 1.74$ & $163.3 \pm 1.5$ & $<0.0001$ \\
\hline $\mathrm{TG}(\mathrm{mg} / \mathrm{dL})$ & $83.9 \pm 3.3$ & $85.7 \pm 3.37$ & 0.6770 \\
\hline $\mathrm{HDL}(\mathrm{mg} / \mathrm{dL})$ & $48.0 \pm 0.5$ & $50.6 \pm 0.6$ & $<0.0010$ \\
\hline LDL (mg/dL) & $91.6 \pm 2.1$ & $97.70 \pm 1.87$ & 0.0510 \\
\hline Insulin ( $\mu \mathrm{U} / \mathrm{mL})$ & $13.3 \pm 0.4$ & $13.7 \pm 0.4$ & 0.4000 \\
\hline HOMA-IR & $3.0 \pm 0.1$ & $3.07 \pm 0.10$ & 0.5420 \\
\hline Systolic BP (mmHg) & $106.3 \pm 0.7$ & $101.9 \pm 0.7$ & $<0.0001$ \\
\hline Diastolic BP (mmHg) & $64.4 \pm 0.6$ & $63.7 \pm 0.6$ & 0.3320 \\
\hline Ferritin $(\mu \mathrm{U} / \mathrm{L})$ & $50.5 \pm 2.3$ & $30.6 \pm 1.3$ & $<0.0001$ \\
\hline $\operatorname{Iron}(\mu \mathrm{U} / \mathrm{dL})$ & $114.70 \pm 2.67$ & $99.9 \pm 2.4$ & $<0.0001$ \\
\hline
\end{tabular}

Values are presented as mean \pm standard error.

$\mathrm{Hb}$, hemoglobin; Hct, hematocrit; WBC, white blood cell; FBS, fasting blood sugar; TC, total cholesterol; TG, triglycerides; HDL, high-density lipoprotein; LDL, low-density lipoprotein; HOMA-IR, homeostasis model assessment for insulin resistance; BP, blood pressure.

${ }^{a}$ Missing data were excluded for P-value computation in relevant univariable analysis.

b)Weighted proportion. 

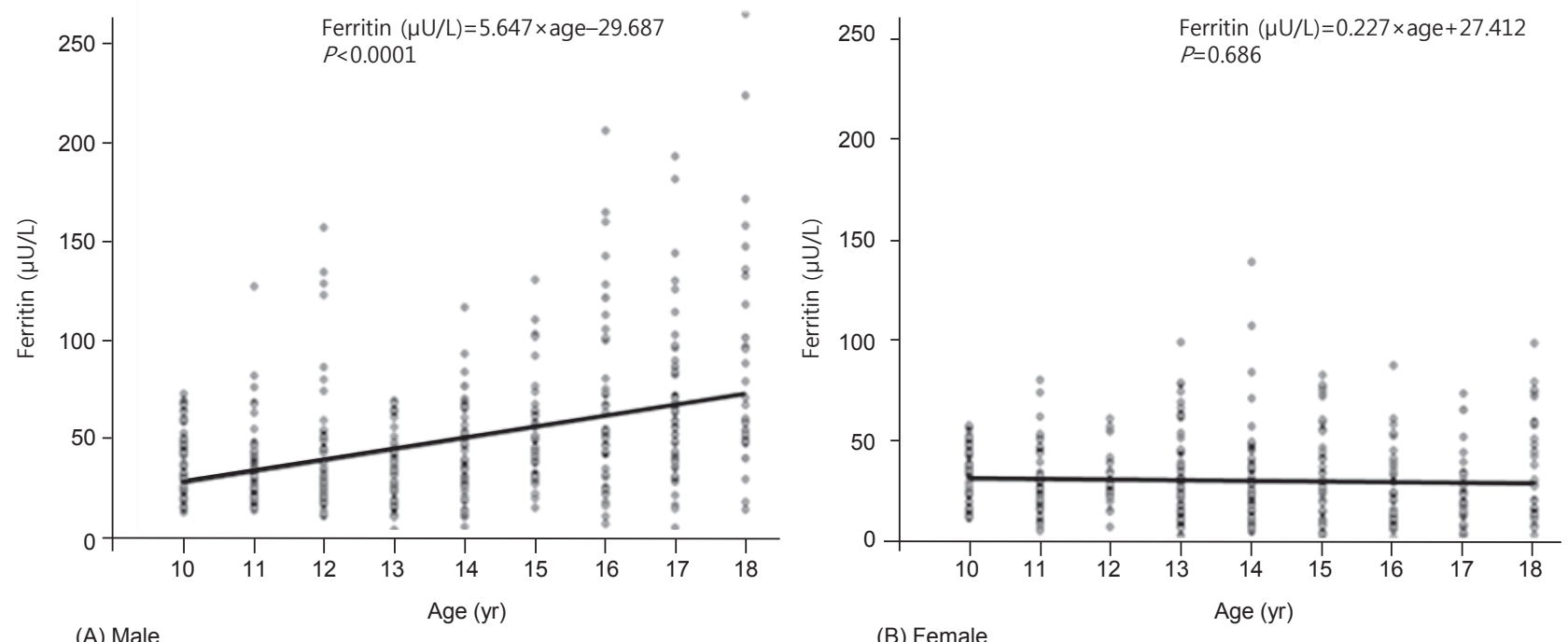

Fig. 1. Significant positive association between serum ferritin level and age in the males ( $A: \beta=5.647, P<0.0001$ ), but not in the females ( $B: \beta=0.227, P=0.686$ ).

Table 2. Characteristics and laboratory data for subjects in the obesity and normal group of Korean adolescents

\begin{tabular}{|c|c|c|c|c|c|c|}
\hline \multirow{2}{*}{ Characteristic } & \multicolumn{3}{|c|}{ Male $(n=462)$} & \multicolumn{3}{|c|}{ Female $(n=387)$} \\
\hline & Normal & Obesity & $P$-value $e^{\text {a) }}$ & Normal & Obesity & $P$-value \\
\hline Subjects & $400(86.6)$ & $62(13.4)$ & - & $354(91.5)$ & $33(8.5)$ & - \\
\hline Age (yr) & $14.2 \pm 0.1$ & $14.5 \pm 0.5$ & 0.5090 & $14.0 \pm 0.2$ & $15.4 \pm 0.5$ & 0.005 \\
\hline $\mathrm{Hb}(\mathrm{g} / \mathrm{dL})$ & $14.6 \pm 0.1$ & $14.8 \pm 0.2$ & 0.1790 & $13.3 \pm 0.1$ & $13.3 \pm 0.1$ & 0.655 \\
\hline Hct (\%) & $42.8 \pm 0.2$ & $43.7 \pm 0.5$ & 0.0590 & $39.6 \pm 0.2$ & $39.7 \pm 0.4$ & 0.910 \\
\hline WBC $\left(10^{9} / L\right)$ & $6.0 \pm 0.1$ & $6.9 \pm 0.2$ & $<0.0001$ & $6.0 \pm 0.1$ & $6.8 \pm 0.2$ & 0.001 \\
\hline FBS (mg/L) & $88.8 \pm 0.4$ & $91.1 \pm 1.1$ & 0.0400 & $88.3 \pm 0.4$ & $89.9 \pm 1.8$ & 0.401 \\
\hline $\mathrm{TC}(\mathrm{mg} / \mathrm{dL})$ & $149.5 \pm 1.6$ & $170.7 \pm 5.2$ & 0.0001 & $163.5 \pm 1.5$ & $161.7 \pm 5.1$ & 0.740 \\
\hline TG (mg/dL) & $77.2 \pm 2.7$ & $126.8 \pm 9.4$ & $<0.0001$ & $83.3 \pm 3.5$ & $107.0 \pm 11.4$ & 0.043 \\
\hline $\mathrm{HDL}(\mathrm{mg} / \mathrm{dL})$ & $48.6 \pm 0.5$ & $44.0 \pm 1.5$ & 0.0020 & $51.4 \pm 0.6$ & $43.5 \pm 1.8$ & $<0.001$ \\
\hline LDL (mg/dL) & $86.1 \pm 2.0$ & $119.8 \pm 6.4$ & 0.0001 & $97.6 \pm 1.8$ & $99.4 \pm 7.0$ & 0.791 \\
\hline Insulin ( $\mu \mathrm{U} / \mathrm{mL})$ & $12.1 \pm 0.3$ & $20.9 \pm 1.4$ & $<0.0001$ & $13.3 \pm 0.4$ & $17.0 \pm 1.7$ & 0.021 \\
\hline HOMA-IR & $2.7 \pm 0.1$ & $4.7 \pm 0.3$ & $<0.0001$ & $2.9 \pm 0.1$ & $3.8 \pm 0.4$ & 0.014 \\
\hline Systolic BP (mmHg) & $104.8 \pm 0.8$ & $116.1 \pm 1.8$ & $<0.0001$ & $101.7 \pm 0.7$ & $103.1 \pm 1.5$ & 0.344 \\
\hline Diastolic BP (mmHg) & $63.7 \pm 0.7$ & $69.0 \pm 1.6$ & 0.0030 & $63.61 \pm 0.6$ & $64.4 \pm 1.2$ & 0.529 \\
\hline Ferritin $(\mu \mathrm{U} / \mathrm{L})$ & $47.7 \pm 2.0$ & $68.9 \pm 9.4$ & 0.0270 & $29.6 \pm 1.3$ & $39.8 \pm 6.6$ & 0.133 \\
\hline Iron $(\mu \mathrm{U} / \mathrm{dL})$ & $114.6 \pm 2.8$ & $115.0 \pm 6.2$ & 0.9520 & $99.0 \pm 2.6$ & $07.6 \pm 6.2$ & 0.204 \\
\hline
\end{tabular}

Values are presented as number (\%) or mean \pm standard error.

$\mathrm{Hb}$, hemoglobin; Hct, hematocrit; WBC, white blood cell; FBS, fasting blood sugar; TC, total cholesterol; TG, triglyceride; HDL, high-density lipoprotein; LDL, low-density lipoprotein; HOMA-IR, homeostasis model assessment for insulin resistance; BP, blood pressure.

${ }^{a}$ Missing data were excluded for $P$-value computation in relevant univariable analysis

b) Weighted proportion

$\mathrm{mg} / \mathrm{dL}$ vs. $97.6 \pm 1.8 \mathrm{mg} / \mathrm{dL}, P=0.791)$, systolic BP $(103.1 \pm 1.5$ $\mathrm{mmHg}$ vs. $101.7 \pm 0.7 \mathrm{mmHg}, P=0.344)$, diastolic BP $(64.4 \pm 1.2$ $\mathrm{mmHg}$ vs. $63.61 \pm 0.6 \mathrm{mmHg}, P=0.529)$, ferritin $(39.8 \pm 6.6 \mu \mathrm{U} /$ $\mathrm{L}$ vs. $29.6 \pm 1.3 \mu \mathrm{U} / \mathrm{L}, P=0.133)$ and iron $(107.6 \pm 6.2 \mu \mathrm{U} / \mathrm{dL}$ vs. $99.0 \pm 2.6 \mu \mathrm{U} / \mathrm{dL}, P=0.204$ ) than the normal group (Table 2).

\section{The associations between serum ferritin and components of MS and obesity in Korean adolescents}

In male adolescent, after adjusting for age, associations were observed between serum ferritin and abdominal obesity $(\beta=12.98, P=0.021)$ and obesity $(\beta=21.196, P=0.016)$. Other MS components and obesity-related factors do not appear to be associated with serum ferritin (all $P>0.05$ ). But In female, no significant associations were observed between serum ferritin and obesity, abdominal obesity, or other MS components (Table 3). 


\section{Discussion}

Serum ferritin is a major iron storage protein in all cell types such as in the liver and spleen (L-isoferritin), and in the heart and kidneys (H-isoferritin), and its distribution patterns are different according to age, sex, and race ${ }^{13,27)}$.

Previous studies have investigated the relationship between obesity, central obesity and serum ferritin. Lecube et al. ${ }^{11)}$ reported that factors accounting for high ferritin levels in obesity; Gillum et al. ${ }^{13)}$ reported that serum ferritin is associated with waist-to-hip ratio, indices of body fat distribution, and obesity in Mexican-American men; and Oshaug et al. ${ }^{28)}$ reported that BMI and waist-to-thigh ratio is the strongest predictor of serum ferritin in healthy, young men.

In this study, we analyzed 2010 K-NHANES data for 849 Korean children and adolescents (aged 10-18 years) to examine the associations between serum ferritin and both obesity and components of MS. The results show that the prevalence of obesity is $13.4 \%(62 / 462)$ in male and $8.5 \%$ (33/387) in female. Serum ferritin appears to be significantly different between the sexes. In male, mean serum ferritin level was markedly higher than in female, and serum ferritin increased significantly with increasing age. Unlike in male, we did not observe a trend toward increasing serum ferritin with age in female, which is consistent with the results of previous studies conducted in Japanese children ${ }^{29,30)}$. Although the mechanisms are unclear, it has been hypothesized that sex differences and aging-related changes in serum ferritin might be related to menstruation in female. When we analyzed serum ferritin between girls without and with menarche, there is no significant difference between two group (mean \pm SE, $31.8 \pm 1.6$ vs. $30.4 \pm 1.7, P=0.549$ ).

According to International Diabetes Federation (IDF) criteria, adolescents with abdominal obesity ( $\mathrm{WC} \geq 90^{\text {th }}$ percentile for age and sex) and 2 or more of the following criteria: TG, $\geq 150 \mathrm{mg} /$ $\mathrm{dL}$; HDL, $\leq 40 \mathrm{mg} / \mathrm{dL}$; fasting glucose, $\geq 100 \mathrm{mg} / \mathrm{dL}$; and systolic $\mathrm{BP}, \geq 130 \mathrm{mmHg}$; or diastolic $\mathrm{BP}, \geq 85 \mathrm{mmHg}$ were diagnosed with MetS. In our results, the prevalence of MS based on the IDF consensus ${ }^{31)}$ is $0.005 \%$ (4/849). Because of small number of MS, we couldn't find a relationship between ferritin and MS.

In male, serum ferritin, WBC count, FBS, TC, TG, LDL, insulin, HOMA-IR, and systolic and diastolic BP were significantly higher and HDL was significantly lower in the obesity group than in the normal group. In female, WBC, TG, insulin, and HOMA-IR levels were significantly higher and HDL levels were significantly lower in the obesity group than in the normal group. After adjusting for age, serum ferritin was positively associated with both abdominal obesity $(\beta=12.98$, $P=0.021)$ and obesity $(\beta=21.196, P=0.016)$ in male. However, we did not find an association between serum ferritin and obesity in female. These results are consistent with previous studies that found that serum ferritin was associated with obesity and visceral obesity ${ }^{9,13-18,21,22,32-34)}$

BMI is an excellent indicator for accurately measuring body fat and is a very specific and reliable indicator of childhood obesity, and WC is frequently used as an indicator of abdominal obesity $^{25,35)}$.

Recent studies have shown an association between obesity and low-grade chronic inflammation resulting from chronic activation of the innate immune system, which is characterized by abnormal cytokine production, increased acute-phase reactants, and activation of inflammatory signaling pathways ${ }^{8,36)}$

In the past, adipose tissue was thought of as just a reservoir of energy stored as TG. However, many recent studies have reported additional functions of adipocytes, such as their being dynamic endocrine cells that secrete free fatty acids and inflammatory cytokines (tumor necrosis factor [TNF]-alpha and interleukin [IL]-6, adiponectin, plasminogen activator inhibitor-1, leptin and resistin $)^{8)}$. TNF-alpha and IL-6 trigger different key steps in the insulin-signaling pathway, thus affecting insulin sensitivity. Adiponectin has insulin-sensitizing and anti-inflammatory properties ${ }^{37,38)}$.

Iron is a transitional metal capable of causing oxidative stress-induced tissue damage by catalyzing the conversion of hydrogen peroxide to free radicals that attack cellular membranes, proteins, and DNA ${ }^{18,22,34,39)}$. That cellular or tissue damage might lead to insulin dysfunction, such as insulin resistance and pancreatic $\beta$-cell dysfunction ${ }^{15,34)}$. Hepatic iron overload decreases hepatic insulin extraction and contributes to peripheral hyperinsulinemia ${ }^{15,40)}$. Also, ferritin is an acutephase reactant, and elevated serum ferritin concentrations reflect systemic inflammation, which is involved in the pathophysiologic mechanisms of insulin resistance and diabetes $^{21,24)}$.

The relationships with insulin resistance and inflammation

Table 3. The association between serum ferritin level and metabolic syndrome components in male Korean adolescents

\begin{tabular}{lcccc}
\hline & \multicolumn{4}{c}{ Ferritin } \\
\cline { 2 - 5 } Metabolic syndrome component & $\beta$ & Standard error & Crude $(P$-value) & Adjusted $(P$-value $)$ \\
\hline $\mathrm{FBS} \geq 100(\mathrm{mg} / \mathrm{L})$ & -1.598 & 12.290 & 0.897 & 0.436 \\
$\mathrm{TG} \geq 150(\mathrm{mg} / \mathrm{dL})$ & 7.065 & 9.292 & 0.448 & 0.589 \\
$\mathrm{HDL} \leq 40(\mathrm{mg} / \mathrm{dL})$ & 8.025 & 7.104 & 0.261 & 0.167 \\
$\mathrm{SBP} \geq 130$ or $\mathrm{DBP} \geq 85(\mathrm{mmHg})$ & 24.244 & 17.461 & 0.167 & 0.471 \\
$\mathrm{WC} \geq 90$ th & 12.980 & 9.969 & 0.195 & 0.021 \\
$\mathrm{BMl} \geq 95$ th or $\mathrm{BMl} \geq 25\left(\mathrm{~kg} / \mathrm{m}^{2}\right)$ & 21.196 & 9.453 & 0.027 & 0.016 \\
\hline
\end{tabular}

Tested by linear analysis and adjusted by age.

FBS, fasting blood sugar; TG, triglyceride; HDL, high-density lipoprotein; SBP, systolic blood pressure; DBP, diastolic blood pressure; WC, waist circumference; BMI, body mass index, 
are similar for serum ferritin and obesity. Furthermore, the activation of inflammatory cytokines in obesity increases the transcription of ferritin messenger RNA, which transfers ferritin to hepatocytes ${ }^{9}$. These findings suggest that obesity and elevated serum ferritin may be related.

To our knowledge, no studies have shown associations among obesity, serum ferritin, and metabolic disorders in healthy Korean children and adolescents or on an association between increases in serum ferritin and aging. Hence, the results of our study could aid in developing measures for managing and improving the health of obese adolescents.

In conclusion, we observed associations between serum ferritin and abdominal obesity and obesity in Korean male adolescents. We suggest that serum ferritin could be used as an indicator for obesity or metabolic disorders in children. Further research, including longitudinal studies, is necessary to confirm these relationships.

\section{Conflict of interest}

No potential conflict of interest relevant to this article was reported.

\section{References}

1. Lob-Corzilius T. Overweight and obesity in childhood--a special challenge for public health. International journal of hygiene and environmental health 2007;210:585-9.

2. Kim SY, Shin DH, Kim HJ, et al. Fasting Insulin Level in Obese Children: Relationship to Comorbidities of Childhood Obesity. J Korean Soc Pediatr Endocrinol 2004;9:186-93.

3. Oh K, Jang MJ, Lee NY, et al. Prevalence and trends in obesity among Korean children and adolescents in 1997 and 2005. Korean J Pediatr 2008;51:950-5.

4. Rossner S. Childhood obesity and adulthood consequences. Acta paediatrica 1998;87:1-5.

5. Dietz WH. Health consequences of obesity in youth: childhood predictors of adult disease. Pediatrics 1998;101:518-25.

6. Slyper AH. Childhood obesity, adipose tissue distribution, and the pediatric practitioner. Pediatrics 1998;102:e4.

7. Whitaker RC, Wright JA, Pepe MS, Seidel KD, Dietz WH. Predicting obesity in young adulthood from childhood and parental obesity. N Engl J Med 1997;337:869-73.

8. Weiss R, Caprio S. The metabolic consequences of childhood obesity. Best practice \& research Clinical endocrinology \& metabolism 2005;19:405-19.

9. Choi KM, Lee KW, Kim HY, et al. Association among serum ferritin, alanine aminotransferase levels, and metabolic syndrome in Korean postmenopausal women. Metabolism: clinical and experimental 2005;54:1510-4.

10. Gabay C, Kushner I. Acute-phase proteins and other systemic responses to inflammation. The New England journal of medicine 1999;340:448-54.

11. Lecube A, Hernandez C, Pelegri D, Simo R. Factors accounting for high ferritin levels in obesity. International journal of obesity (2005) 2008;32:1665-9.

12. Gonzalez AS, Guerrero DB, Soto MB, Diaz SP, MartinezOlmos M, Vidal O. Metabolic syndrome, insulin resistance and the inflammation markers C-reactive protein and ferritin. European journal of clinical nutrition 2006;60:8029.

13. Gillum RF. Association of serum ferritin and indices of body fat distribution and obesity in Mexican American men--the Third National Health and Nutrition Examination Survey. Int J Obes Relat Metab Disord 2001;25:639-45.

14. Iwasaki T, Nakajima A, Yoneda M, et al. Serum ferritin is associated with visceral fat area and subcutaneous fat area. Diabetes Care 2005;28:2486-91.

15. Kang HT, Linton JA, Shim JY. Serum ferritin level is associated with the prevalence of metabolic syndrome in Korean adults: the 2007-2008 Korean National Health and Nutrition Examination Survey. Clin Chim Acta 2012;413:636-41.

16. Jehn M, Clark JM, Guallar E. Serum ferritin and risk of the metabolic syndrome in U.S. adults. Diabetes Care 2004;27:2422-8.

17. Lee BK, Kim Y, Kim YI. Association of serum ferritin with metabolic syndrome and diabetes mellitus in the South Korean general population according to the Korean National Health and Nutrition Examination Survey 2008 Metabolism 2011;60:1416-24.

18. Yoo KD, Ko SH, Park JE, et al. High serum ferritin levels are associated with metabolic risk factors in non-obese Korean young adults: Korean National Health and Nutrition Examination Survey (K-NHANES) IV. Clin Endocrinol (Oxf) 2012;77:233-40.

19. Piperno A, Trombini P, Gelosa M, et al. Increased serum ferritin is common in men with essential hypertension. J Hypertens 2002;20:1513-8.

20. Williams MJ, Poulton R, Williams S. Relationship of serum ferritin with cardiovascular risk factors and inflammation in young men and women. Atherosclerosis 2002;165:17984.

21. Kim CH, Kim HK, Bae SJ, Park JY, Lee KU. Association of elevated serum ferritin concentration with insulin resistance and impaired glucose metabolism in Korean men and women. Metabolism: clinical and experimental 2011;60:414-20.

22. Pham NM, Nanri A, Yi S, et al. Serum ferritin is associated with markers of insulin resistance in Japanese men but not in women. Metabolism 2013;62:561-7.

23. Kim CW, Chang Y, Sung E, Shin H, Ryu S. Serum ferritin levels predict incident non-alcoholic fatty liver disease in healthy Korean men. Metabolism 2012;61:1182-8.

24. Ford ES, Cogswell ME. Diabetes and serum ferritin concentration among U.S. adults. Diabetes Care 
1999;22:1978-83.

25. Freedman DS, Ogden CL, Berenson GS, Horlick M. Body mass index and body fatness in childhood. Curr Opin Clin Nutr Metab Care 2005;8:618-23.

26. Korea Centers for Disease Control and Prevention. Standards growth charts of Korean children and adolescents in 2007. Seoul: Korea Centers for Disease Control and Prevention, 2007.

27. Zacharski LR, Ornstein DL, Woloshin S, Schwartz LM. Association of age, sex, and race with body iron stores in adults: analysis of NHANES III data. Am Heart J 2000;140:98-104.

28. Oshaug A, Bugge KH, Bjonnes CH, Borch-Iohnsen B, Neslein IL. Associations between serum ferritin and cardiovascular risk factors in healthy young men. A cross sectional study. European journal of clinical nutrition 1995;49:430-8.

29. Ueno Y, Fujita K, Takashina N, et al. Studies on the change in the levels of serum ferritin, serum iron and total iron binding capacity caused by aging and sex difference. Rinsho Byori 1991;39:523-30.

30. Yamashita N, Oba K, Nakano H, Metori S. Age-related changes in concentrations of ferritin, glyeosylated ferritin, and non-glycosylated ferritin. Nihon Ronen Igakkai Zasshi 1996;33:754-60.

31. Zimmet P, Alberti KG, Kaufman F, et al. The metabolic syndrome in children and adolescents - an IDF consensus report. Pediatric diabetes 2007;8:299-306.
32. Ryu SY, Kim KS, Park J, Kang MG, Han MA. Serum ferritin and risk of the metabolic syndrome in some Korean rural residents. J Prev Med Public Health 2008;41:115-20.

33. Weiss R, Dziura J, Burgert TS, et al. Obesity and the metabolic syndrome in children and adolescents. N Engl J Med 2004;350:2362-74.

34. Park SK, Ryoo JH, Kim MG, Shin JY. Association of serum ferritin and the development of metabolic syndrome in middle-aged Korean men: a 5-year follow-up study. Diabetes care 2012;35:2521-6.

35. Dietz WH, Robinson TN. Use of the body mass index (BMI) as a measure of overweight in children and adolescents. The Journal of pediatrics 1998;132:191-3.

36. Bastard JP, Maachi M, Lagathu C, et al. Recent advances in the relationship between obesity, inflammation, and insulin resistance. European cytokine network 2006;17:4-12.

37. Tchernof A, Despres JP. Pathophysiology of human visceral obesity: an update. Physiological reviews 2013;93:359-404.

38. Whitehead JP, Richards AA, Hickman IJ, Macdonald GA, Prins JB. Adiponectin--a key adipokine in the metabolic syndrome. Diabetes, obesity \& metabolism 2006;8:264-80.

39. Andrews NC. Disorders of iron metabolism. N Engl J Med 1999;341:1986-95.

40. Wilson JG, Lindquist JH, Grambow SC, Crook ED, Maher JF. Potential role of increased iron stores in diabetes. The American journal of the medical sciences 2003;325:332-9. 